\title{
THE APPLICATION OF NURSING THEORY “SELF CARE OREM" IN NURSING CARE OF MULTIPAROUS PREGNANCY WITH ANAEMIA: A CASE REPORT
}

\author{
Siti Nurbayanti Awaliyah ${ }^{1}$, Setyowati ${ }^{2}$, Tri Budiati ${ }^{3}$ \\ ${ }^{1}$ School of Health Sciences Jenderal Achmad Yani Cimahi, Cimahi, Indonesia \\ ${ }^{2,3}$ Faculty of Nursing Universitas Indonesia, Depok, Indonesia \\ Correspondence: beby.awaliyah@yahoo.com
}

\begin{abstract}
Anemia in pregnancy is a major concern of health problem during pregnancy, as it is associated with the increase of maternal and infant morbidity and mortality cases. Multiparous pregnant women have a higher risk of anemic during their pregnancies. The nurse specialist of maternity has the crucial roles to help multiparous pregnant women with anemia in filling their basic needs due to various nursing problems. Methodology in this article used the case studies approach on seven multiparous pregnant women with anemia. Several nursing issues emerged are the risk of injury both to the mother and to the fetus, dizziness, limited activities and limited knowledge of anemia. The self-care theory focused on an individuals' ability to fill their self-needs by paying attention to the level of dependent care. The application of self-care theory is suitable for multiparous pregnant women with anemia as it helps them to be independent patients. Nurses may use the Orem framework as a guide in conducting the nursing process.
\end{abstract}

Keywords: anemia, multiparous pregnant women, self-care

\section{INTRODUCTION}

Pregnancy is a period of physiological changes in body systems due to the growth and development of the fetus. In pregnancy, the requirement of iron in women's body increases and should be fulfilled to prevent anemia (Bashiri, et al. 2003). Anemia affects a half billion (496 million) women in reproductive ages worldwide. $29 \%$ of them were nonpregnant women and $38 \%$ (32.4 million) of pregnant women aged 15-49 years in 2011. The highest anemia prevalence was in South Asia and Africa (central and western) (Steven, et al. 2013). Currently, anemia in pregnancy is a global public health problem, especially in developing countries (Noronha, et al. 2012).

The results of Riskesdas (2013) found that the prevalence of anemia in pregnant women in Indonesia was $37.1 \%$. Anemia is an indirect cause of maternal death. Based on Indonesia's demographic and health survey (IDHS, 2012), the maternal mortality rate (MMR) in Indonesia was 359 per 100,000 live births. The most common cause of maternal death was bleeding (RI Ministry of Health, 2014). Anemia in pregnancy is associated with mortality and morbidity in mothers and 
Siti Nurbayanti Awaliyah : The Application of Nursing Theory "Self Care Orem” In Nursing Care

infants due to the risk of miscarriage, babies dying at birth, prematurity, and low birth weight (WHO, 2014).

Anemia is the condition of the number, size of red blood cells, and concentration of hemoglobin, which is less than $11 \mathrm{gr} / \mathrm{dl}$. These conditions interfere with the capacity of the blood to carry oxygen throughout the body (WHO, 2014). The causes of anemia in pregnant women are iron deficiency, acute blood loss, inflammation, malignancy, megaloblastic anemia, hemolytic anemia, aplastic, hypoplastic, and hereditary anemia. The causes of hereditary anemia include thalassemia, sickle cell hemoglobinopathy, hemoglobinopathy, and hereditary hemolytic anemia (Bashiri, et al. 2003). Half of the cases are caused by iron deficiency (Resolution WHA 65.6, 2012). Iron deficiency threatens individual well-being, causes fatigue, lethargy, and impaired physical capacity and work performance (Horton \& Ross, 2003).

The risk of anemia increases in women with high parity, which is three times higher in women with 2-3 children, and four times higher in women with four or more children (UcheNwachi EO, et al. 2010). High parity is one of the risk factors for anemia in pregnancy (Rooney, C. 1992). WHO defines high parity is pregnancy $\geq 5$, pregnancy period $\geq 20$ weeks. While low parity is pregnancy $\leq 5$ and pregnancy period is $\geq 20$ weeks (Aliyu, 2005). According to Astriana (2017) research, there is a relationship between the incidence of anemia in pregnancy, parity, and the age of pregnant women.

According to research by Khairil, et al (2013) which applied a qualitative approach found that one of the causes of anemia was lack of nutrition. Factors that cause include cultural factors as an inhibitor of adequate nutritional intake; lack of knowledge and exposure to information related to nutritional needs of pregnant women; lack of family support in providing adequate nutrition during 
Siti Nurbayanti Awaliyah : The Application of Nursing Theory "Self Care Orem” In Nursing Care

pregnancy; inability to provide adequate nutrition during pregnancy; the decision making process for food selection in the family affects failure in meeting nutritional needs during pregnancy.

The role of specialist maternity nurses as providers of nursing care holistically is very much needed by applying nursing theory including in the multiparous pregnant women with anemia case. One of the nursing theories that can be used is self-care theory. The model of self-care Orem's concept aims to help mothers achieve independence through personal abilities. Self-care is done for them to maintain life, health, development, and well-being (Tomey \& Alligood, 2010). According to Orem, there are five methods that can be used to help clients, including behaving or acting on behalf of individuals, guiding or orienting individuals, providing physical or psychological support, developing environments to help and support individual needs, and training individuals (Orem, 2001). Multiparous pregnant women with anemia need help in fulfilling care. Methods of meeting needs with the Orem approach can be used for nursing intervention and implementation. Based on this background, the application of nursing care to multiparous pregnant women with anemia was carried out using self-care theory.

\section{METHODS}

The method used was a case study of seven cases of multiparous pregnant women with anemia consisting of six inpatient cases of maternal anemia and one outpatient case.

\section{Case 1}

Mrs. S, 29 years old, G2P1A0, 37 weeks pregnant, a private employee, Diploma level education, Islam, Javanese, married. Husband identity 30-year-old and private employee. Clients visited the referral hospital from the PHC for the blood transfusion program because of anemia. Women felt dizziness and weakness. The physical assessment found patient looked weak, pale, 
Siti Nurbayanti Awaliyah : The Application of Nursing Theory "Self Care Orem" In Nursing Care

anemic conjunctiva, and $<2$ seconds CRT. Blood Pressure 120/70 mmHg, Pulse 84 x / minutes, temperature 36.20C, respiration 16 x / minutes, $\mathrm{Hb} 7.4 \mathrm{gr} / \mathrm{dl}, \mathrm{Ht} 27 \%$, BB $58 \mathrm{~kg}$, TB $156 \mathrm{~cm}$. The client stated that she feels dizzy because she has minus eyes The mother had blood transfused 453 cc. The client felt anxious about her condition because it was time to give birth. Nursing problems that identified including are the risk of injury to the mother and the fetus, disturbances in comfort: dizziness, activity intolerance, and anxiety about the disease.

\section{Case 2}

Mrs. I, 36 years, G2P1A0, 12 weeks pregnant, a housewife, junior high school, Moslem, Betawi tribe, married status. Husband 39-year-old, laborer. Clients come to the hospital because of HEG and anemia. Complaints felt by dizziness, weakness and abdominal pain due to nausea and vomiting. At the time of physical examination, it looked weak, pale, anemic conjunctiva, $<2$ seconds CRT. TD 110/70 mmHg, Pulse 64 x / minute, temperature 36.4 0C, respiration 18 x / minute, $\mathrm{Hb} 8.3 \mathrm{gr} / \mathrm{dl}, \mathrm{Ht} 29 \%$, BB currently $46 \mathrm{~kg}$ from the previous $56 \mathrm{~kg} .155 \mathrm{~cm}$ TB. Nursing problems included the risk of injury to the mother, the risk of injury to the fetus, disturbances in comfort: dizziness, nutrition less than body needs and activity intolerance.

\section{Case 3}

Mrs. R, 32 years old, G2P1A0, 37 weeks pregnant, housewife, junior high school, Moeslem, Sundanese, married status. 38-husband years old, laborer. Clients visited the referral hospital from the clinic for a blood transfusion because of anemia. Client's symptoms included of weakness, sometimes dizziness. physical examination found the mother looks pale, anemic conjunctiva, CRT $<2$ seconds, appearance is not tidy. TD 90/60 mmHg, Pulse 78x / minute, Temperature 36,70C, Respiration 18 x / minute, $\mathrm{Hb} 8$ gr / dl (three times $\mathrm{Hb}$ ), Ht 30\%, BB 54 kg, TB 156 cm. Currently 
Siti Nurbayanti Awaliyah : The Application of Nursing Theory "Self Care Orem” In Nursing Care

32 weeks pregnant. One month ago the client was planned for transfusion but the patient refused because according to her the feeling of dizziness felt came from low blood pressure. Nursing problems that occur to the client are the risk of injury to the mother, the risk of injury to the fetus, disturbances in comfort: dizziness and readiness to increase knowledge.

\section{Case 4}

Mrs. VM, 29 years, G3P2A0 is 37 weeks pregnant, housewife, High School Education, Christianity, Batak tribe, married. husband 34 years old, entrepreneur. Clients visited the referral hospital from the clinic for a blood transfusion because of anemia. Client's symptoms included dizziness and weakness. The maternal assessment found pale, anemic conjunctiva, CRT $<2$ seconds, the activity can be done alone. The patient's appearance is less tidy and looks weak. TD 110/70 mmHg, pulse 86x / minute, temperature 36,40C, respiration 16 x / minute, $\mathrm{Hb} 8 \mathrm{gr} / \mathrm{dl}, \mathrm{Ht}$ $30 \%$. Previous pregnancies had anemia. The client is worried about her current condition because SC is scheduled Nursing problems that occur in these clients were a risk of injury to the mother, the risk of injury to the fetus, a feeling of comfort: dizziness, anxiety about the medical procedure that will be followed.

\section{Case 5}

Mrs. NP, 31 years old, G6P4A1 34 weeks pregnant, laborers, Vocational Education, Moeslem, Betawi tribe, married. 34-husband years old, a motorcycle taxi driver. Clients visited the referral hospital from the PHC for a blood transfusion due to anemia. Client symptoms included dizziness and weakness. The maternal assessment found pale, anemic conjunctiva, CRT $<2$ seconds, sometimes feeling contractions but disappearing, lack of enthusiasm for activity, TD 110/60 mmHg, pulse 68x / minute, temperature 36,50C, respiration 20 x / minute, Hb $8.2 \mathrm{gr} / \mathrm{dl}$. Ht 30\%. Clients though that symptoms such as dizziness because they have a history of low BP. 
Siti Nurbayanti Awaliyah : The Application of Nursing Theory "Self Care Orem" In Nursing Care

Nursing problems that arise were the risk of injury to the mother and fetus, disturbances in comfort: dizziness, limited activity, and readiness to increase knowledge.

\section{Case 6}

Mrs. M, 26 years old, G2P1A0 34 weeks pregnant, housewife, Vocational Education, Moeslem, Betawi tribe, married. husband 30 years old, entrepreneur. The client visited the obstetrical policlinic in the hospital to control her health after one-week post-transfusion. Clients have been treated for anemia. The history of $\mathrm{Hb}$ was $6.5 \mathrm{gr} / \mathrm{dl}$. Patients' symptoms were a weakness, easily tired and dizzy. The results of the assessment include women looked pale, anemic conjunctiva, CRT <2 seconds, less eager to do activities at home and assisted by the mother and her husband. BB $53 \mathrm{~kg}, 155 \mathrm{~cm} \mathrm{~TB}$, TD 110/70 mmHg, pulse 80 x / minute, temperature $36.80 \mathrm{C}$, respiration 20 x / minute, $\mathrm{Hb} 8.6 \mathrm{gr} / \mathrm{dl}$, Ht 30\%, Ferritin 9. Nursing problems identified the risk of injury to the mother, risk of injury to the fetus, fatigue, anxiety, activity intolerance and readiness to improve health knowledge.

\section{Case 7}

Mrs. N, 24 years, G2P1A0 33 weeks pregnant, housewife, Elementary School Education, Islam, Sundanese, married. Husband 27 years old, entrepreneur. The client visited the referral hospital for a blood transfusion because of anemia. Patients' symptoms included dizziness, weakness, and easily tired. The physical assessment found pale, anemic conjunctiva, CRT <2 seconds, during pregnancy, did not like to eat meat and fish. BB $69 \mathrm{~kg}, 158 \mathrm{~cm} \mathrm{~TB}, 120 / 80 \mathrm{mmHg}$ TD, pulse 86 x / minute, temperature $36.60 \mathrm{C}$, respiration 20 x / minute, $\mathrm{Hb} 7.1 \mathrm{gr} / \mathrm{dl}, \mathrm{Ht} 25 \%$. Nursing problems were the risk of injury to the mother and the fetus, disturbances in comfort: dizziness, self-care deficits and readiness to increase knowledge. 
Siti Nurbayanti Awaliyah : The Application of Nursing Theory "Self Care Orem" In Nursing Care 


\section{Integration of Orem Self Care Theory in Multiparous Women with Anemia}

The application of Orem's self-care nursing theory is as follows:

\section{Self Care}

Conditioning Factor: personal and environment factor

Universal self-care: multiparous pregnant women with anemia,

Development of self-care: the patient appears weak, pale, anemic conjunctiva.

Health deviation: all patients were treated and lab tests $(\mathrm{Hb})$ were carried out, experiencing limitations in fulfilling self-care.

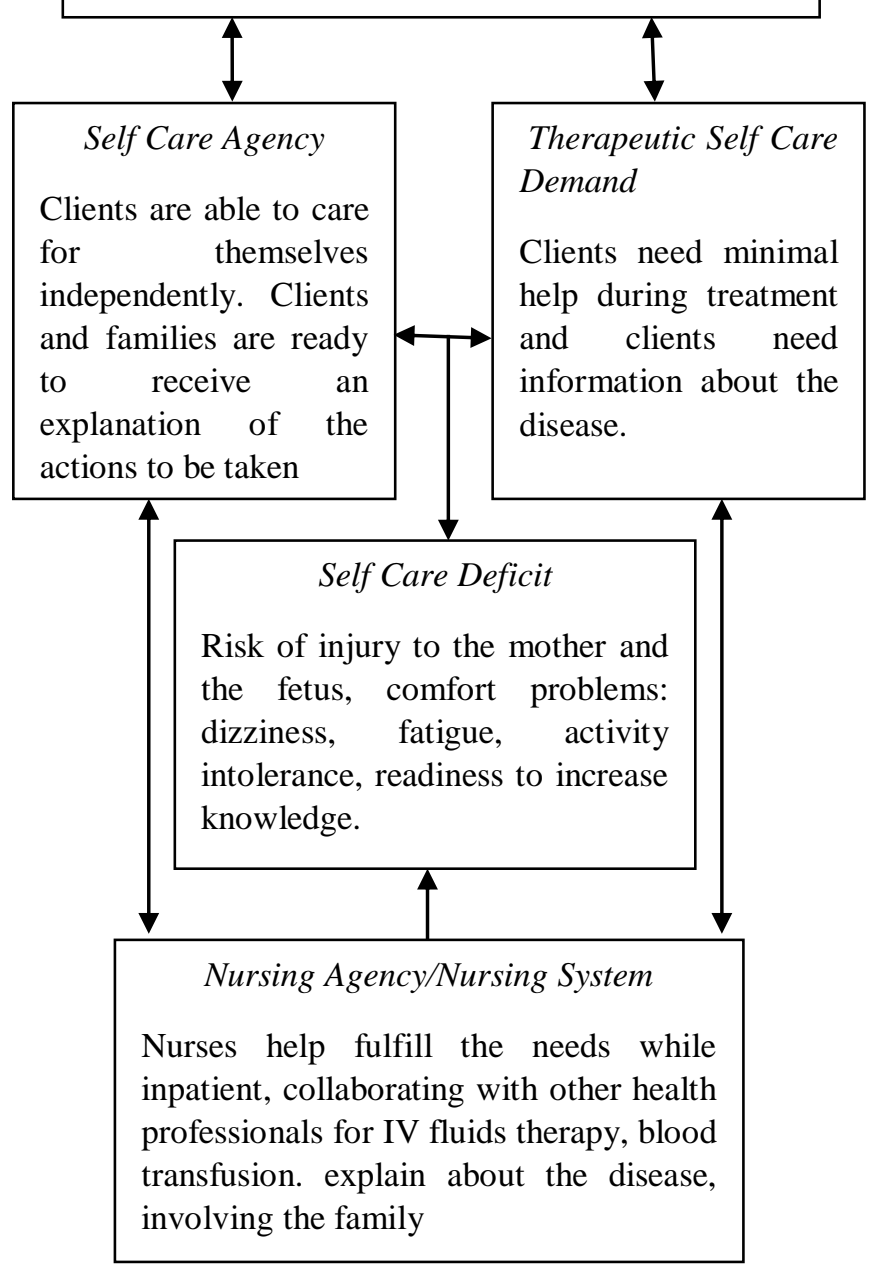

Figure 2.2 Orem Self Care for Multiparous Pregnant Women with Anemia 
Siti Nurbayanti Awaliyah : The Application of Nursing Theory "Self Care Orem” In Nursing Care

\section{RESULTS}

The application of self-care theory in multiparous pregnant women with anemia aimed to improve their ability to care for themselves. Self-care theory can help nurses in carrying out a comprehensive nursing process so that patients are independent in their care (Orem, 2012). The nursing process in the seven cases used Orem's nursing self-care theory. The patients' condition found that six cases of hospitalization indicated for blood transfusion and one case (case 6) of a one-week post-transfusion outpatient client. Clients visited a hospital for pregnancy control and consultation results from the obstetrician's lab. The age-based assessment found that younger pregnant women had lower hemoglobin values. According to Noronha, et al (2012) the factors that contribute to anemia include young age, grand multipara \& ethnicity.

Based on parity status, it was found that the seven cases were multiparous pregnant women. The multiparous pregnant women have a greater risk of anemia in pregnancy. This is in line with Uche-Nwachi EO, Odekunde A, Jacinto S, Burnett M, Clapperton M, David Y, et al's (2010) study, stated that the risk of anemia increased three times higher for women who have children $2-3$, and four times higher in women with 4 or more children. In healthy pregnancies, the hormonal changes cause an increase in plasma volume which causes a decrease in hemoglobin. One out 7 cases found that anemia occurred in the sixth pregnancy with a history of premature labor. According to Rooney (1996), mentioned that high parity is a risk factor for anemia in pregnancy. Anemic pregnant women with high parity are more at risk of bleeding (Farsi, Brooks, Werler, Cabral, \& Al-shafei, 2011).

There is a case that anemia in pregnancy occurred in the first trimester and six cases occurred in the third trimester. According to Horowitz, Ingardia, \& Borgida (2013), increasing blood volume in pregnancy would be affected hemoglobin levels especially from 6 weeks to 35 
Siti Nurbayanti Awaliyah : The Application of Nursing Theory "Self Care Orem” In Nursing Care

weeks' gestation, then hemoglobin increases one month before delivery. This is due to an increase in blood volume on average by almost $50 \%$ due to the expansion of plasma volume and the mass of red blood cells.

Two of the 7 cases experienced anemia in previous pregnancies, five cases considered anemia because of other factors such as minus eyes and a low blood history. The symptoms appeared including dizziness experienced in a previous pregnancy, but the patient did not check to a health facility. Pregnant women were not aware of anemia, it may be related to women's educational status. According to Casanova (2006), the risk factors for anemia in pregnancy include a vegetarian diet, menstrual disorders before pregnancy, education level, high parity, hyperemesis gravidarum, and poverty level.

This study found all patients have symptoms of dizziness and weakness. According to Bashiri, Burstein, Sheiner, \& Mazor (2003), anemia is manifested: pale skin or mucosa, lack of energy and shortness of breath, signs, and symptoms that appear depend on the severity of anemia. Whereas according to Horowitz, Ingardia, \& Borgida (2013), symptoms of anemia in pregnancy include easy fatigue, lethargy, and headaches. These symptoms increase the risk of birth of low birth weight babies, preterm birth, perinatal death, lactation failure, and postpartum depression. Fatigue is associated with poor quality of life (Straus, Testa, Sarokhan, et al. 2006).

One case found that patient had abdominal pain, nausea, and vomiting. This happens because of her gestation age was 12 weeks and the patient had hyperemesis gravidarum. This condition occurred because of inadequate nutritional intake during pregnancy in anemic women. Anemia has multifactorial causes including complex interactions between nutrition, infectious diseases, and other factors. This complexity is a challenge in overcoming determinants factors in 
Siti Nurbayanti Awaliyah : The Application of Nursing Theory "Self Care Orem” In Nursing Care

anemia (Balarajan, Ramakrishnan, Özaltin, Shankar, \& Subramanian, 2011). One patient was less consumption of meat and fish, she preferred vegetable sources nutrition than animal sources. As a result, patients have lacked of foods containing iron, protein, vitamins and other important nutrients (Khairil, et al. 2013). The iron deficiency that associated with nutrition is a major cause of anemia worldwide especially women in reproductive age and pregnancy. Iron requirements increase six to seven times from the beginning of pregnancy to the end (Christensen RD \& Ohls, 2004). The experience of pregnancy and childbirth is a personal factor that would affect a patient's ability to perform self-care both related to universal needs and developmental functions.

The application of the self-care theory in seven cases found that five cases were the second pregnancy, one case was the third pregnancy, and one case was the sixth pregnancy. Six cases carried out transfusion, they were in the third trimester, the transfusion aimed to prevent complications of pregnancy and childbirth. Complications of anemia in pregnancy to women and fetus include preterm birth, low birth weight births, intrauterine growth issues, stillbirth, rupture membranes and risk of infection (Milman, et al. 1999). Anemia has a negative impact on health status. Patients with anemia have lower health recovery rates, the condition is associated with poor health status and dependency when hospitalized. Low hemoglobin levels are associated with decreased muscle strength and impaired physical functions (Maraldi et al., 2006).

The assessment of health deviation self-care acquisitions found that seven cases were carried out laboratory tests. The results of hemoglobin examination showed that pregnant women had moderate (moderate) anemia with a hemoglobin value of 7-8.9 gr/dl. Mireku et al (2015) reported that there was a relationship between anemia and hemoglobin $\leq 9 \mathrm{~g} / \mathrm{dl}$ with lower cognitive and motor development in one-year-old children. All cases had a blood transfusion. This intervention is used as supportive care for the treatment of anemia (Goodnough \& Panigrahi, 2017). 
Siti Nurbayanti Awaliyah : The Application of Nursing Theory "Self Care Orem” In Nursing Care

One case was examined for ferritin. Serum ferritin is a stable glycoprotein that accurately reflects iron storage. Serum ferritin examination is generally considered the best test for assessing iron deficiency in pregnancy, although this is an acute phase reactant and its level will increase when there is active infection or inflammation (Pavord, et al. 2011). In patients who are hospitalized, serum ferritin examination is not carried out because it has not become a standard of examination and there are no facilities for conducting ferritin tests.

Self-care agency is a condition that clients are able to care themselves independently. Clients and families received an explanation of the actions to be taken. Therapeutic self-care demand found that all patients need minimal help from nurses. Nursing supportive educative actions were given in six cases because they did not know about anemia in pregnancy. The seven cases had a blood transfusion and hospitalization, and one case was outpatient. Indications for transfusion in all cases because the patient was in the final trimester of pregnancy. The administration of Fe tablets continued until the time of delivery. Pregnant women are given counseling about the importance of consuming foods that contain lots of iron such as vegetables, fruits, consumption of eggs, meat and liver.

Nursing diagnoses, in this case, included the risk of injury due to anemia both in the mother and fetus, disturbances in comfort: dizziness, activity intolerance, readiness to increase knowledge. Nursing problems the risk of complications of pregnancy and childbirth and the risk of injury to the fetus found in all cases. This may because of the influence of anemia is very dangerous for the pregnancy, both mother and fetus. Problems of comfort: all patients feel dizzy even at different intensities. The difference in intensity of dizziness is caused by gestational age, age at pregnancy, history of having hypotension and activities that patients do on a daily basis. Activity intolerance 
Siti Nurbayanti Awaliyah : The Application of Nursing Theory "Self Care Orem” In Nursing Care

arises in seven cases at different levels. The level of dependence on activities differs in seven cases. Knowledge deficits occur in six cases, pregnant women feel that patients' symptoms during pregnancy are a normal common sign.

Changes that occur in patients with anemia would cause a decrease in self-care agency (ability) of patients in meeting their self-care demand (needs that must be met) called self-care deficit. The role of nurses is needed in helping individuals to meet self-care needs in accordance with therapeutic self-care demand so that independence can be achieved through the nursing system (Dennis, 1997). Nursing as a nursing agency helps pregnant women with anemia to overcome the limitations of self-care deficit taking into account the level of individual hanging.

In the seven cases, the level of treatment ability found in six cases of pregnant women with anemia treated led to a partial level of dependence so that the nursing intervention provided in the form of minimal assistance (partially compensatory system), meaning the author helps to meet some of the patient's self-care needs that cannot be met by involving the family. Other interventions in the form of supportive educative systems are given to one case because the patient is outpatient so that the client is able and able to learn to do the necessary self-care with the guidance from nurses.

Supportive educative implementation is carried out by the author with the aimed to provide accurate information to patients and families so that patients would perform healthy behavior and make the right decisions. In making patients anemic in pregnancy, the authors do it in stages which are adjusted to the level of dependence and ability of the patient.

The expected evaluation of nursing care for multiparous pregnant women with anemia and family is to fulfill self-care needs independently. The patient would maintain the health of herself 
Siti Nurbayanti Awaliyah : The Application of Nursing Theory "Self Care Orem” In Nursing Care

and the fetus in the womb. Nursing problems that arise in the client can be overcome, even though their achievements require different times.

\section{CONCLUSION}

The theory of self-care is effective as the main theory for nursing care in multiparous pregnant women with anemia. Nurses have a role in facilitating patients to learn and to meet their self-care needs in accordance with their level of dependence. All cases are managed, the level of patient's dependence is mild dependence category so that the nursing interventions was a partially compensatory and supportive educative system by giving care and providing health education to patients and families.

The application of Orem's self-care nursing theory treats patients as individuals who have the ability to fulfill their universal needs and developmental needs, not as dependent individuals even with health problems. The concept is very possible to apply in nursing care for pregnant women with anemia.

Orem's self-care theory is applied to nursing care effectively. Maternity nurses should enhance their ability and sensitivity in understanding patients' and their potency. Nurses should learn how to control themselves and not consider patients as objects of nursing care. In addition, nurses need to learn continuously in order to be able to carry out their roles and functions in providing nursing care through maximum nursing practice.

\section{REFERENCES}

Astriana (2017). Kejadian anemia pada Ibu Hamil ditinjau dari paritas dan usia. Jurnal Aisyiah. Vol. 2, No. 2. https://ejournal.stikesaisyah.ac.id/index.php/jika/article/view/WA 
Siti Nurbayanti Awaliyah : The Application of Nursing Theory "Self Care Orem" In Nursing Care

Aliigood \& Tomey (2006). Nursing theorist and their work. Missoury: Mosby.

Bashiri, A., Burstein, E., Sheiner, E., \& Mazor, M. (2003). Anemia during pregnancy and treatment with intravenous iron: review of the literature. European Journal of Obstetrics \& Gynecology and Reproductive Biology, Vol. 110, 2-7. https://doi.org/10.1016/S0301$\underline{2115(03) 00113-1}$

Christensen RD, Ohls RK (2004): Anaemias unique to pregnancy and the perinatal period In Wintrobe's clinical hematology. Volume 2. 11th edition. Edited by: Greer JP, Foerster J, Lukens NJ, Rodgers GM, Paraskevas F, Glader B. USA: Lippincott Williams and Wilkins; $1467-1486$.

Farsi, Y. M., Brooks, D. R., Werler, M. M., Cabral, H. J., \& Al-shafei, M. A. (2011). Effect of high parity on occurrence of anemia in pregnancy: a cohort study. BMC Pregnancy and Childbirth, Vol.11:7, 1-7. https://doi.org/10.1186/1471-2393-11-7.

Balarajan, Y., Ramakrishnan, U., Özaltin, E., Shankar, A. H., \& Subramanian, S. V. (2011).

Anaemia in low-income and middle-income countries. The Lancet, 378(9809), 2123-2135. https://doi.org/10.1016/S0140-6736(10)62304-5

Goodnough, L. T., \& Panigrahi, A. K. (2017). Blood Transfusion Therapy. Medical Clinics of North America, 101(2), 431-447.https://doi.org/10.1016/j.mcna.2016.09.012

Maraldi, C., Volpato, S., Cesari, M., Cavalieri, M., Onder, G., Mangani, I., Pahor, M. (2006). Anemia and recovery from disability in activities of daily living in hospitalized older persons. Journal of the American Geriatrics Society, 54(4), 632-636. https://doi.org/10.1111/j.15325415.2006.00664.x 
Siti Nurbayanti Awaliyah : The Application of Nursing Theory "Self Care Orem” In Nursing Care

Milman N, Bergholt T, Byg K-E, Eriksen L, Graudal N. (1999). Iron status and iron balance during pregnancy: a critical reappraisal of iron supplementation. Acta Obstet Gynecol Scand Vol;78(9):749-57

Mireku MO, Davidson LL, Koura GK, et al. (2015). Prenatal hemoglobin levels and early cognitive and motor functions of one-year-old children. Pediatrics Vol;136 (1):e76-83.

Horton S, Ross J. The economics of iron deficiency. Food Policy. 2003;28: 51-75. doi:10.1016/S0306-9192(02)00070-2.

Kemenkes RI (2012), Riset Kesehatan Dasar (2013). Jakarta: Badan Penelitian dan Pengembangan Kementrian Kesehatan RI (2013).

Kemenkes RI (2014). Infodatin Situasi Kesehatan Ibu. Jakarta: Pusat data dan informasi Kemenkes RI.

Kementrian Kesehatan RI (2014). Profil Kesehatan Indonesia 2014. Jakarta: Pusat Data dan Informasi Kementrian Kesehatan RI 2015.

Khairil, et al. (2013). Kegagalan memutuskan pemenuhan kebutuhan nutrisi selama kehamilan: Studi Grounded Theory Pada Ibu Hamil Anemia. Jurnal Keperawatan Indonesia, Volume 16 $\begin{array}{lllllll}\text { No.2, Juli 2013, hal 85-92. pISSN 1410-4490, eISSN } 2354 & -9203 .\end{array}$ DOI:http://dx.doi.org/10.7454/jki.v16i2.6

Noronha, J. A., Khasawneh, E. Al, Seshan, V., Ramasubramaniam, S., \& Raman, S. (2012). Anemia in Pregnancy - Consequences and Challenges: A Review of Literature. Journal of South Asian Federation of Obstetrics and Gynecoloy, 4 (1), 64-70. Retrieved from http://siteresources.worldbank.org

Orem, D.E. (2001). Nursing concept of practice. Philadelphia: Mosby Year Book, Inc.

Orem, D. E. (20012). Nursing concepts of practice (6th ed.). St. Louis, Mosby. 
Siti Nurbayanti Awaliyah : The Application of Nursing Theory "Self Care Orem" In Nursing Care

Pavor, et al. (2011). UK guidelines on the management of iron deficiency in pregnancy. London: British Society for Haematology.

Purbadewi \& Ulvie (2015). Hubungan tingkat pengetahuan tentang anemia dengan kejadian anemia pada ibu hamil. Jurnal Gizi Universitas Muhammadiyah Semarang. Vol. 2, No. 1. 3139. https://jurnal.unimus.ac.id/index.php/jgizi/article/viewFile/754/808

Resolution WHA65.6. Comprehensive implementation plan on maternal, infant and young child nutrition. In: Sixty - fifth World Health Assembly Geneva, 21-26 May 2012. Resolutions and decisions, annexes. Geneva: World Health Organization; 2012:12-13 (http://www.who.int/nutrition/topics/WHA65.6_resolution_en.pdf?ua=1, accessed 01 January 2018).

Rooney, C. (1992) Antenatal care and maternal health: how effective is it? Areview of the evidence. World Health Organization (WHO). Geneva: MSM/92.4.

Stevens G, Finucane M, De-Regil L, Paciorek C, Flaxman S, Branca F et al.; Nutrition Impact Model Study Group (Anaemia). Global, regional, and national trends in haemoglobin concentration and prevalence of total and severe anaemia in children and pregnant and nonpregnant women for 1995-2011: a systematic analysis of population-representative data. Lancet Global Health. 2013; 1: e16-e25. doi: 10.1016/S2214-109X(13)70001-9.

Straus DJ, Testa MA, Sarokhan BJ, et al. (2006). Quality-of-life and health benefits of early treatment of mild anemia: a randomized trial of epoetin alfa in patients receiving chemotherapy for hematologic malignancies. Cancer;107:1909-17.

Uche-Nwachi EO, Odekunde A, Jacinto S, Burnett M, Clapperton M, David Y, et al. (2010). Anaemia in pregnancy: associations with parity, abortions and child spacing in primary healthcare clinic attendees in Trinidad and Tobago. Journal African Health Sciences, 10(1), 
Siti Nurbayanti Awaliyah : The Application of Nursing Theory "Self Care Orem" In Nursing Care

66-70. Retrieved from https://www.ncbi.nlm.nih.gov/pmc/articles/PMC2895803/

World Helath Organization (WHO, 2012). Guideline: Daily iron and folic acid supplementation in pregnant women. Geneva: WHO Press.

WHO (2011). Hemoglobin concentrations for the diagnosis of anemia and assessment of severity. Vitamin and Mineral Nutrition Information System. Geneva: WHO Press.

WHO (2014). WHA Global Nutrition Targets 2015: Anemia Policy Brief. Geneva: WHO Press. 